\title{
Михайло Зубрицький, Зібрані твори і матеріали у трьох томах, т. 2: Матеріали до біографіï, редкол. Франк Сисин [et al.], Львів: Літопис, 2016, 614 ss. + il."
}

Ksiądz Mychajło Zubryćkyj (1856-1919) całkiem do niedawna był w Polsce w ogóle nieznany, a jego prace niecytowane. Tymczasem jego osoba i dzieła mogą zainteresować przedstawicieli różnych dziedzin humanistycznych i specjalizacji. O niezwykłości tej postaci świadczy fakt, iż ów ksiądz, autor przeszło 340 artykułów prasowych i prac historyczno-etnograficznych, znawca Bojkowszczyzny, ale i komentator ówczesnego życia publicznego, snuł swoje refleksje i prowadził naukowe badania, pracując nie - jak mogłoby się wydawać - na uniwersyteckiej katedrze czy w sejmowych ławach, lecz w wiosce Mszaniec pod Starym Samborem (ówczesny powiat staromiejski), w której - jak podaje Słownik geograficzny Królestwa Polskiego i innych krajów słowiańskich - mieszkało pod koniec XIX wieku niespełna tysiąc mieszkańców ${ }^{1}$. Nie przeszkodziło to Zubryćkiemu w utrzymywaniu kontaktów z ruską inteligencją we Lwowie (m.in. z Iwanem Franką czy Wołodymyrem Hnatiukiem) ani we współpracy z Towarzystwem Naukowym im. Szewczenki. Z publikacji Zubryćkiego, rozproszonych po licznych periodykach, wyłania się wielowymiarowy obraz dawnej Bojkowszczyzny, swoisty mikrokosmos środkowej Galicji czy też - patrząc z dzisiejszej perspektywy - polsko-ukraińskiego pogranicza. Przerwanie pracy naukowej i społecznej Zubryćkiego nastąpiło wraz z wybuchem I wojny światowej. W 1914 roku został najpierw przesunięty do parafii w Berehah Dolnych (dzisiaj Brzegi Dolne), a we wrześniu aresztowano go i na krótko osadzono w obozie koncentracyjnym w Talerhofie wraz z innymi duchownymi greckokatolickimi podejrzanymi o rusofilstwo (co w przypadku Zubryćkiego okazało się bezpodstawne). Uwolniony już po tygodniu został wysłany do Krainy, skąd powrócił do Galicji wiosną 1916 roku. W listopadzie 1918 zaangażował się w działania na rzecz ukraińskiej niepodległości. W trakcie wojny polsko-ukraińskiej o Galicję Wschodnią został aresztowany przez władze polskie, a rychło potem, już po uwolnieniu, zmarł. Życiorys Zubryćkiego stanowi interesujący przykład ukraińskiego patrioty zaangażowanego w badanie kultury swojego narodu.

Tekst powstał w ramach projektu OPUS 13, finansowanego przez Narodowe Centrum Nauki w Krakowie, pt. „Pomiędzy dwoma zjazdami w Pradze. Związki między Słowianami w Europie Środkowej i Południowo-Wschodniej w latach 1848-1908” (2017/25/B/HS3/00240).

1 Stownik geograficzny Królestwa Polskiego i innych krajów słowiańskich, red. F. Sulimierski, B. Chlebowski, W. Walewski, t. 6, Warszawa 1885, s. 783. 
Pomysł zebrania i wydania spuścizny tego autora ze wszech miar zasługuje na uznanie. Obszerność materiału źródłowego pozostawionego przez duchownego-badacza, a także materiałów o nim, wymagała powołania zespołu wydawniczego, który ukonstytuował się w 2009 roku. Jego kierownikiem, a zarazem redaktorem pierwszego tomu został Frank E. Sysyn (Canadian Institute of Ukrainian Studies w Toronto). Opublikowano go w 2013 roku nakładem lwowskiego wydawnictwa Litopys². Przedrukowano w nim 40 prac historycznych i etnograficznych Mychajła Zubryćkiego. Inicjatywę tę od razu dostrzeżono w ukraińskiej, ale i światowej nauce, co potwierdziły liczne recenzje ${ }^{3}$. Również w Polsce publikacja doczekała się odzewu. Najpierw recenzję w „Przeglądzie Historycznym” opublikował Piotr Wróbel ${ }^{4}$ (University of Toronto), następnie zaś szerzej do prac Zubryćkiego odnieśli się Norbert Morawiec 5 (Akademia im. Jana Długosza w Częstochowie) i Danuta Sosnowska ${ }^{6}$ (Uniwersytet Warszawski).

W 2016 roku ukazał się kolejny tom cyklu zatytułowany „Materiały do biografii”. Jego redaktorem i autorem wprowadzenia (,Źródłoznawcze akcenty życia i działalności Mychajła Zubryćkiego") jest Wasyl Sokil z Instytutu Narodoznawstwa NAN Ukrainy, ale w przygotowaniu woluminu brali udział także inni badacze. Już na pierwszy rzut oka widać, że pod względem struktury publikacja ta znacząco różni się od tomu pierwszego. Otóż tom drugi został podzielony aż na sześć części. W pierwszej, zatytułowanej „Materiały biograficzne”, znalazło się dziewięć tekstów biograficznych o Zubryćkim, powstałych między 1905 a 1970 rokiem. Są to nekrologi, noty encyklopedyczne czy w końcu rysy biograficzne skreślone między innymi przez Wołodymyra Hnatiuka, Mychajła Hruszewśkiego, Iwana Krypjakewycza oraz syna bohatera publikacji - Petra Zubryćkiego.

Druga, kluczowa i najbardziej interesująca część publikacji, to „Materiały autobiograficzne". W dziale tym znalazły się trzy narracje autorstwa Zubryćkiego poprzedzone komentarzem krytycznym. Pierwszy z tekstów to dotychczas nigdzie niepublikowana „Autobiografia”, napisana przez duchownego jeszcze w 1896 roku. Być może została ona przygotowana - jak podejrzewa autor przedmowy do tej edycji

2 М. Зубрицький, Зібрані твори і матеріали у трьох томах, т. 1: Наукові праиџі, редкол. Ф. Сисин [et al.], Львів 2013.

3 Tom był recenzowany m.in. przez: Oksanę Kiś z Ukraińskiego Uniwersytetu Katolickiego we Lwowie („Народознавчі зошити” 2013, по. 6 (114), s. 173-175); Wadyma Adadurowa, również wykładowcę Ukraińskiego Uniwersytetu Katolickiego we Lwowie („Orientalia Christiana Periodica” 2014, no. 1, s. 284-287); Roberta B. Klymasza z Uniwersytetu Manitoby („Folklorica: Journal of Slavic and East European, and Eurasian Folklore Association” 2014, vol. 28, s. 35-36); Marko Pavlyshyna z Uniwersytetu Monasha w Melbourne („Australian Slavonic and Eastern European Studies” 2014, vol. 28, nos. 1-2, s. 221-224) oraz Alois Woldan z Uniwersytetu Wiedeńskiego (,Zeitschrift für Slavische Philologie" 2014, Bd. 70, H. 1, s. 197-200).

4 „Przegląd Historyczny” 2013, t. 104, z. 3, s. 624-626.

5 N. Morawiec, Owce, rekruci i machorka. Wokót „Zbioru prac i materiatów” Mychajła Zubryckiego, „Orientalia Christiana Cracoviensia” 2015, vol. 7, s. 117-137.

6 D. Sosnowska, Narration Made Concrete: Overcoming Alienation of Belonging to Inteliggentsia in the Case of Mychajto Zubrycki [w:] Galician Polyphony: Places and Voices, ed. A. Molisak, J. Wierzejska, Warsaw 2015, s. 117-126. 
Wasyl Sokil - na zamówienie lwowskiego encyklopedysty Iwana Łewyćkiego, zbierającego materiały biograficzne o ruskich działaczach w XIX wieku. W swojej autobiografii Zubryćkyj opisał dzieciństwo, młodość, w końcu swoją pracę w parafii w Mszańcu. Wspomnienia duchownego stanowią interesujący materiał źródłowy dla badaczy galicyjskiej prowincji, w tym relacji międzyetnicznych i rozwoju oświaty. Niech za przykład posłuży opowieść autora o jego zetknięciu się z dyrektorem gimnazjum drohobyckiego Tomaszem Barewiczem, we wcześniejszych latach posłem Sejmu Krajowego i Rady Państwa w Wiedniu, typowym - można powiedzieć - gente Rutheni, natione Poloni drugiej połowy XIX wieku. Mychajło Zubryćkyj wspominał go tak (tłum. A.Ś.):

Przychodzę do dyrektora, ks. Tomasza Barewicza, i mówię do niego po rusku. A on mi odpowiada po polsku, żebym się nie bawił w panicza. Ja mu odpowiadam, że mnie nie stać na to, a on i tak swoje. Jakoś będąc w 4 klasie, nie uklęknąłem w cerkwi, a on przestraszył się wówczas, czy ja nie Moskal. Tak przynajmniej zrozumiałem z jego słów. Ksiądz Barewicz bardzo nie lubił, kiedy do niego jakiś uczeń mówił po rusku, wtedy tak odpowiadał: „Albowiem nieprzyzwoitą rzeczą jest mówić po rusku, jeżeli starszy do ucznia po polsku przemawia" [cytat w oryg. po polsku - A.Ś.]. Znaliśmy tę jego słabą stronę i zazwyczaj rozmawialiśmy po rusku. [...] My, Rusini, nie lubiliśmy go jeszcze za to, że wysługiwał się Polakom [s. 65-66].

Reminiscencje, choćby takie jak ta, ukazują charakter zadrażnień między Rusinami a Polakami (także Rusinami przyznającymi się do polskości) nie tyle w wielkiej polityce, ile na prowincji. Nie oznacza to jednak, że między galicyjskimi Rusinami tak ambitnie działającymi na rzecz rozwoju swojej kultury w XIX wieku a dominującą w tym czasie w Galicji polską kulturą istniał mur. Sam Zubryćkyj pisze, jakie polskie gazety czytywał (s. 69, 76-77). Bez wątpienia wspomnienia Zubryćkiego warte byłyby wydania także w języku polskim, pokazują bowiem galicyjską rzeczywistość, tak dobrze znaną z polskojęzycznych świadectw przeszłości, od drugiej strony - ruskiej.

Kolejny tekst autobiograficzny Zubryćkiego to dziennik prowadzony przez niego podczas I wojny światowej. Dziennik ten, poprzedzony wstępem Hryhorija Demjana, był już w Polsce wydany we fragmentach w 2014 roku$^{7}$. Trzeci tekst w tej sekcji to faksymile notatnika duchownego. Na prawie 100 stronach publikacji zamieszczono dobrej jakości kolorowe fotokopie osobistych notatek księdza, które - jak to zazwyczaj w tego typu przypadkach bywa - odnoszą się do wielu zagadnień, pisane są w różnych językach, zawierają wypisy z przeczytanych prac itd. Materiał ten starał się opracować Wasyl Sokil, czego rezultaty przedstawił w krótkim wstępie, ale bez wątpienia dobrym zabiegiem byłaby jednak próba odczytania i edycji tylko tych materiałów, które faktycznie mogłyby wnieść coś nowego do stanu wiedzy o księdzu czy rzeczywistości, w jakiej funkcjonował.

Trzecia część publikacji to edycja listów Zubryćkiego do posła na Sejm Krajowy i do Rady Państwa Ołeksandra Barwinśkiego, dalej do Wołodymyra Hnatiuka, Mychajła Hruszewśkiego, Iwana Franki i innych. Listy opatrzono objaśnieniami

M. Zubrycki, Dziennik, podał do druku F.E. Sysyn, tłum. W. Kudela-Świątek, oprac. A. Świątek [w:] Monarchia, wojna, czlowiek. Codzienne i niecodzienne życie mieszkańców Galicji w czasie pierwszej wojny światowej, red. A.A. Zięba, A. Świątek, Kraków 2014, s. 65-76. 
dotyczącymi adresatów korespondencji oraz terminów występujących w listach, nie zamieszczono jednak niestety żadnego do nich wprowadzenia. Brak ten można jednak częściowo wytłumaczyć tym, że do części listów odnoszą się artykuły zawarte w piątej części pracy.

Komentarzem nie opatrzono także kolejnej, czwartej części publikacji, którą stanowią fotokopie różnych dokumentów Zubryćkiego (metryk, świadectw szkolnych, dyplomów itd.). Część ta co prawda nie wnosi żadnej wartości naukowej, ale znacząco ubogaca od strony estetycznej całe wydawnictwo.

O tym, że recenzowana publikacja nie ma wyłącznie charakteru edycji źródłowej, świadczy obszerna, część piąta. Zawiera ona artykuły naukowe poświęcone osobie Zubryćkiego i jego aktywności, w zdecydowanej większości publikowane już wcześniej w różnych miejscach. W sekcji zamieszczono dwa teksty najlepszego znawcy historii życia Zubryćkiego, zmarłego w 2013 roku Hryhorija Demjana, pod tytułem „Mało znane epizody z życia i naukowej pracy Mychajła Zubryćkiego” oraz „Narodowo-państwowy kierunek działalności Mychajła Zubryćkiego (Tematyczno-bibliograficzny przegląd publikacji)”; dalej Romana Horaka „Fenomen wiejskiego księdza”; Romana Kyrcziwa „Związki Mychajła Zubryćkiego z Iwanem Franką i Wołodymyrem Hnatiukiem”; Hanny Horyń „Praca naukowa Mychajła Zubryćkiego w kontekście epoki”; Hanny Sokil „Z dorobku folklorysty Mychajła Zubryćkiego”; Stefani Hwozdewycz „Mychajło Zubryćkyj - badacz bojkowskiej rodziny i rodzinnych zwyczajów”; Tarasa Romaniuka „Przyczynek do historii czytelni towarzystwa «Proswita» we wsi Mszaniec”; Ołeha Pawłyszyna „«Mychajło Zubryćkyj swoje duszpasterskie obowiązki sumiennie wypełnia». Dziekańska wizytacja parafii Mszaniec w 1904 r.”; Jarosława Tarasa „Mychajło Zubryćkyj w historii kościoła w Mszańcu”; Tetjany Hoszczićkiej „Śladami Mychajła Zubryćkiego (na bazie materiałów terenowych dotyczących architektury ludowej, zebranych we wsiach Mszaniec i Płoskie w rejonie starosamborskim obwodu lwowskiego” oraz Wiry Łysak „Wykorzystanie «kalendarza ludowego» Mychajła Zubryćkiego we współczesnej szkole”. Spośród wymienionych tylko prace Tarasa Romaniuka i Ołeha Pawłyszyna nie były wcześniej publikowane. Reszta to przedruki z różnych wydawnictw.

Ostatnią część książki stanowi wykaz wszystkich opublikowanych (342) i zachowanych w rękopisie (3) prac Mychajła Zubryćkiego. Skorowidz ten stanowi rezultat prac Hryhorija Demjana oraz Wasyla Sokila. We wstępie do tej części Sokil podkreśla, że spora część publikacji była notowana przez samego autora jeszcze za życia w jego notatniku, ale nie zawierała wszystkich pozycji. Zestawienie to posłużyło za podstawę do przygotowania trzeciego tomu cyklu, zawierającego edycję wszystkich prac publicystycznych Zubryćkiego ${ }^{8}$.

Reasumując, należy podkreślić, że drugi tom „Zebranych prac i materiałów” Mychajła Zubryćkiego stanowi godną uznania inicjatywę dokumentacyjną, edytorską i naukową. Zamieszczono $\mathrm{w}$ nim wszystkie znane materiały autobiograficzne $\mathrm{Zu}$ bryćkiego i teksty biograficzne o nim, w tym opracowania naukowe. Część z tych

8 М. Зубрицький, Зібрані твори $i$ матеріали $y$ трьох томах, т. 3: Газетні публікації, етнографічні та архівні матеріали, редкол. Ф. Сисин [et al.], Львів 2018. 
materiałów niewątpliwie zainteresuje polskich badaczy Galicji i relacji polskoruskich w czasach zaborów, ale największą wartością recenzowanego przedsięwzięcia jest zastosowany model wydawniczy. Otóż najpierw wydano wszystkie znane materiały o duchownym. Dopiero później możliwe będzie - na ich podstawie - pisanie biografii Zubryćkiego tudzież analiz jego piśmiennictwa. Sądzę, że dobrze byłoby ten model wydawniczy zastosować w prowadzonych w Polsce badaniach nad innymi znanymi galicyjskimi działaczami (dziennikarzami, politykami, literatami), których spuścizny warto uporządkować i upowszechnić.

\section{Adam Świątek}

(1) http://orcid.org/0000-0003-4256-3496

Uniwersytet Jagielloński w Krakowie

Adres do korespondencji: adam.swiatek@uj.edu.pl 